\title{
Biomass, content, yield and chemical composition of mint (Mentha $x$ villosa Huds.) essential oil in response to withholding irrigation
}

\section{Lucas Ferenzini Alves ${ }^{1}$, Filipe Pereira Giardini Bonfim ${ }^{1}$, Sthefani Gonçalves de Oliveira ${ }^{1}$, Márcio Gonçalves Campos ${ }^{1}$, Cristiane de Oliveira Bolina ${ }^{1}$, Márcia Ortiz Mayo Marques ${ }^{2}$}

\author{
${ }^{1}$ Department of Horticulture, School of Agriculture, Sao Paulo State University, Botucatu, Sao Paulo, Brazil \\ ${ }^{2}$ Plant Genetic Resources Center, Agronomic Institute of Campinas (IAC), Brazil
}

*Corresponding author: lucas.agroecologia@gmail.com

\begin{abstract}
The current work aimed at evaluating the influence of withholding irrigation on biomass production, content, yield and chemical composition of mint essential oil. The experimental design was completely randomized with five treatments and eight repetitions; totally forty plots; being conducted in pots inside a greenhouse for 58 days. The treatments consisted of withholding irrigation (NS) at different levels: control (daily constant irrigation at day zero by withholding irrigation), light NS (withholding irrigation for three days before harvesting), intermediate NS (withholding irrigation for six days before harvesting), severe NS (withholding irrigation for nine days before harvesting) and very severe NS withholding irrigation for twelve days before harvesting). Then, the following characteristics were evaluated: shoot fresh mass (SFM), shoot dry mass (SDM), root fresh mass (RFM), root dry mass (RDM), root volume (RV), conten, yield and chemical composition of mint essential oil. Results indicated that some characteristics were affected by withholding irrigation, such as SFM RFM, RDM, RV and some essential oil components (i.e. 3-octanol; linalool; limonene; p-cymen-8-ol; 3-octanol, acetate; cis- $\beta$-ocimene and cis-Piperitone epoxide). However, there was no significant difference between content and yield. Therefore, the current study showed that suppressing irrigation for 12 days before harvesting (very severe NS) did not affect plant development, since mint is commercialized in dry form.
\end{abstract}

Keywords: Mentha $x$ villosa Huds, water stress, medicinal plants.

Abbreviations: Shoot fresh mass (SFM), shoot dry mass (SDM), root fresh mass (RFM), root dry mass (RDM), root volume (RV).

\section{Introduction}

Lately, researchers are studying about plants adaptation to adverse environments, which involves both plant primary and secondary metabolism, since secondary metabolite levels change in response to environmental conditions (Harborne, 1997). Under stress conditions, plants adaptation is influenced by duration and magnitude of exposure, as well as species genetic variability. Considering that, active principles concentration is related to genetic control, genotype and environment interactions, which can be triggered by stress conditions, e.g. excess or deficiency of some environmental factor, i.e. water, light, temperature, nutrients and others (Andrade and Casali, 1999). Terpenoid compounds are examples of essential oils; such compound presents isoprene as the major component, which comes from the mevalonic acid pathway. When these oils are under water stress, they protect the plant against herbivorous insect attack by providing better living conditions (Taiz and Zeiger, 2013). The production and storage of mint essential oil (Mentha $\mathrm{x}$ villosa Huds. Lamiaceae) takes place in the peltate glandular trichomes, which are found in the aerial parts of plants. Thus, vegetative growth is crucial for determining crop yield and secondary metabolite levels (Wildung and Croteau, 2005). A literature research has been conducted and found just one study about one Mentha specie, such paper investigated biological activities and essential oil produced by the leaves. Moreover, Mentha $\mathrm{x}$ villosa Huds specie is a hybrid derived from Mentha sipicata $x$ Mentha suaveolens and belongs to Lamiaceae family, i.e. plants with medicinal and aromatic traits. This specie is commonly found all over Brazil, in addition to be widely used in chemical, pharmaceutical and food industries (Paulus et al., 2005). In Brazil, irrigation is the most important use of water with a withdrawal rate of $55 \%$ (ANA, 2016). The management of water resources in agriculture must adopt appropriate practices for conserving water (Pereira et al., 2009). The current study aimed at evaluating the use of withholding irrigation technique to assess mint's behaviour by analysing biomass production, yield, content and essential oil composition to establish better irrigation practice without negatively affecting crop development.

\section{Results and discussion}

\section{Biomass production}

Results indicated significant differences by withholding irrigation in SFM, RFM, RDM and RV through analysis of variance. However, there was no difference in SDM (Table 1). By increasing water suppression level, shoot fresh mass and roots developed slowly, Meira et al. (2013) studied 
Table 1. F-test value and analysis of variance and coefficient of variation of root dry mass (RDM, expressed in grams), root fresh mass (RFM, expressed in grams), shoot dry mass (SDM expressed in grams), shoot fresh mass (SFM expressed in grams) and root volume (RV expressed in millilitres), submitted to withholding irrigation (NS) at different levels: 0 days (control, constant irrigation), 3 days (light NS), 6 days (intermediate NS), 9 days (severe NS) and 12 days (very severe NS). School of Agriculture, Botucatu, São Paulo, Brazil, 2014.

\begin{tabular}{lllllll}
\hline SOURCE & DF & RDM & RFM & SDM & SFM & RV \\
\hline $\begin{array}{l}\text { Treatment } \\
\text { Error }\end{array}$ & 4 & $7.12^{* *}$ & $18.14^{* *}$ & $1.76^{\text {ns }}$ & $21.18^{* *}$ & $18.84^{* *}$ \\
\hline $\begin{array}{l}\text { Total } \\
\text { CV }(\%)\end{array}$ & 35 & 39 & 28.1 & 31.49 & 11.62 & 24.8 \\
\hline
\end{tabular}

${ }^{\text {ns }}$ Not significant, ${ }^{* *}$ Significant at $1 \%$ probability

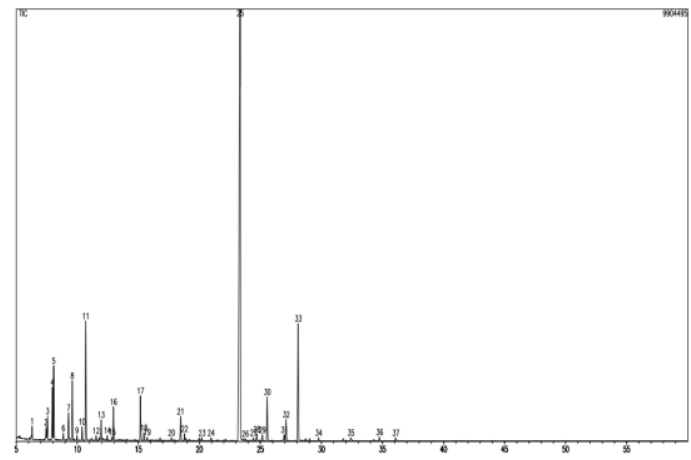

Fig 1. Mint essential oil profile (Mentha $x$ villosa) obtained by GC-MS. 1) $\alpha$-Pinene; 2 ) sabinene; 3) $\beta$-pinene; 4) myrcene; 5$) 3$ octanol; 6) $\alpha$-terpinene; 7) limonene; 8 ) cis- $\beta$-ocimene; 9) trans- $\beta$-ocimene; 10$) \gamma$-Terpinene, 11 ) trans-4-Thujanol; 12$)$ terpinolene; 13) linalool; 14) acetate 1-octen-3-ol; 15) unidentified; 16) 3-octanol, acetate; 17) terpinen-4-ol; 18) p-Cyimen-8-ol; 19) $\alpha$-terpineol; 20) cis-3-hexenyl 3-metilbutanoate; 21) cis-Piperitone epoxide; 22) unidentified; 23) unidentified; 24) ethyl n-nonanila; 25) piperitenone oxide; 26 ) $\alpha$-copaene; 27) $\beta$-elemene; 28) unidentified; 29) unidentified; 30) trans-caryophyllene; 31) $\alpha$-humulene; 32) trans- $\beta$-farnesene; 33) germacrene $D$; 34) $\delta$-cadinene; 35) unidentified; 36) $\alpha$-cadinol; 37$)$ unidentified. School of Agriculture, Botucatu, São Paulo, Brazil, 2014.

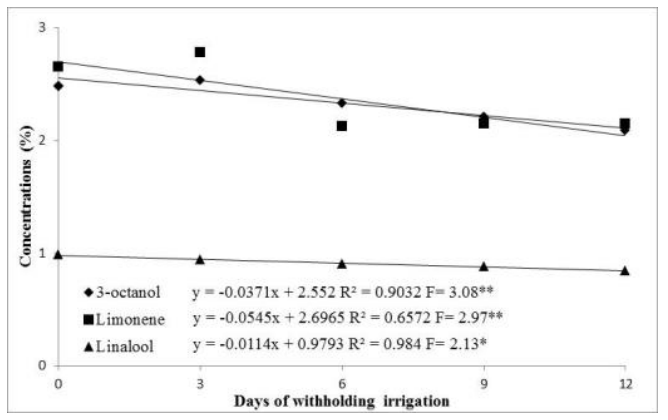

Fig 2. Concentrations of 3-octanol, limonene, linalool, 3-octanol, submitted to withholding irrigation (NS) at different levels: 0 days (control, constant irrigation), 3 days (light NS), 6 days (intermediate NS), 9 days (severe NS) and 12 days (very severe NS ). School of Agriculture, Botucatu, São Paulo, Brazil, 2014.

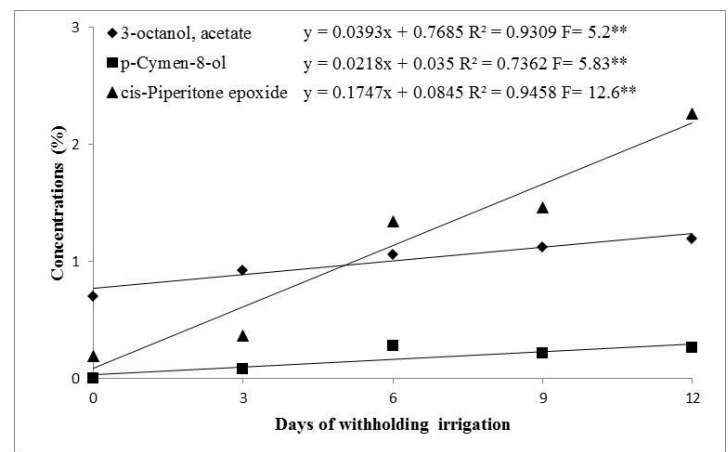

Fig 3. Concentrations of 3-octanol acetate, p-Cymen-8-ol, cis-Piperitone epoxide submitted to withholding irrigation (NS) at different levels: 0 days (control, constant irrigation), 3 days (light NS), 6 days (intermediate NS), 9 days (severe NS) and 12 days (very severe NS ). School of Agriculture, Botucatu, São Paulo, Brazil, 2014. 
Melissa officinalis L. and observed a decrease in shoot fresh and dry phytomass production due to water stress.

These results show the functional balance within plants, i.e. water uptake by roots and photosynthesis on shoots. Therefore, roots uptake nutrients and water to help promote shoot growth, then water can be considered a growth limiting factor. When plants are subjected to water deficit, root tip starts losing turgor, i.e. affecting plants growth rate (Taiz and Zeiger, 2013).

Different results were found in a study byPravuschi et al. (2010), who observed no effect on irrigation blades in Basil roots development (Ocimum basilicum L.), that is, dry mass and root length did not differ.

\section{Essential oil production}

There were no significant differences in the CONTENT and YIELD traits with averages values of $0.21 \%, 10 \mathrm{mg} / 50 \mathrm{~g}$ of plant in control treatment; $0.20 \% ; 10 \mathrm{mg} / 50 \mathrm{~g}$ of plant in the light NS; $0.26 \%, 13 \mathrm{mg} / 50 \mathrm{~g}$ of plant in the intermediate NS; $0.27 \%, 11 \mathrm{mg} / 50 \mathrm{~g}$ of plant in the severe NS and $0.22 \%, 9$ $\mathrm{mg} / 50 \mathrm{~g}$ of plant at the very severe NS. Similar results were found by Pravuschi et al. (2010), whose Basil essential oil content (Ocimum basilicum L.), blade $100 \%$ on Class-A Tank (ECA), did not differ significantly from the amounts obtained without irrigation. Such responses are at odds with Abbaszadeh et al. (2009) and Farahani et al. (2009), which reported a decrease in essential oil of Melissa officinalis $L$ by suppressing irrigation.

Moreover, Marcum and Hanson (2006) reported a significant decrease in the production of peppermint essential oil (Mentha $\mathrm{x}$ piperita L.) by suppressing irrigation blades to evapotranspiration in California.

\section{Essential oil composition}

20 substances were identified through chemical composition analysis of the essential oil, being piperitenone oxide (51\%) the major component. Followed by germacrene-D (8.3\%), trans-4-Thujanol (5.8\%), cis- $\beta$-ocimene (4.0\%). This analysis was confirmed in all experimental plots (Fig 1). A similar result was observed in Mentha $\mathrm{x}$ villosa, in which piperitenone oxide was the major component (55.4\%)and cis- $\beta$-ocimene (3.5\%) (Matos et al., 1999).

By withholding irrigation, six chemical oil constituents were affected, as they presented significant differences in their concentrations. Figure 2 shows that three components decreased linearly within treatments, i.e. 3-octanol, limonene and linalool. However, 3-octanol, acetate; pcymen-8-ol and cis-Piperitone epoxide increased, while irrigation was more intensely suppressed (Fig 3 ).

By assessing water stress in spearmint (Mentha spicata L.), Delfine et al. (2005) observed higher limonene and linalool concentrations, according to increasing levels of water stress, not befitting the findings of the current study.

These changes may be a consequence of water stress on the enzymes involved in the biosynthesis of monoterpenes in essential oil composition, (Shabih Fatima et al., 2002). Withholding irrigation enables better use of water without losing dry biomass, quantity and quality of the essential oil. Results showed that the levels of irrigation suppression did not affect shoot dry mass, content, yield and the oil's major component. Therefore, withholding irrigation for 12 days before harvesting (very severe NS) can be promoted without damaging crop development, since mint is commercialized in dry form to industries.

\section{Materials and methods}

\section{Plant material}

Seedlings were purchased from a local producer and each seedling was transplanted into a single pot.

\section{Experimental design and study's setting}

The experimental design was completely randomized with five treatments and eight repetitions, totalling forty plots. All treatments were conducted in pot inside the greenhouse for 58 days between August 28 and October 24, 2014. The greenhouse is located at the Horticulture Department, São Paulo State University, School of Agriculture, Botucatu, São Paulo, Brazil. During the experiment, the daily temperature were $25.8 \stackrel{\circ}{\circ} \mathrm{C}$ (average maximum temperature) and $14.4{ }^{\circ} \mathrm{C}$ (average minimum temperature). Therefore, the greenhouse temperature was kept at around $30 \circ \mathrm{C}$ and humidityin $70 \%$.

\section{Plant treatments}

The treatments consisted of withholding irrigation (NS) at different levels: control (daily constant irrigation at day zero by withholding irrigation), light NS (withholding irrigation for three days before harvesting), intermediate NS ( withholding irrigation for six days before harvesting), severe NS (withholding irrigation for nine days before harvesting) and very severe NS withholding irrigation for twelve days before harvesting).

\section{Soil classification}

The soil was classified as Red Nitosol, and presented the following chemical properties: $\mathrm{pH}_{\text {water }} 5.7 ; \mathrm{P}_{\text {Resin }}-73 \mathrm{mg} \mathrm{dm}^{-3}$; $\mathrm{K} 7.6 \mathrm{mmol} \mathrm{dm}^{-3}$; Ca $30 \mathrm{mmol} \mathrm{dm}^{-3}$; Mg $14 \mathrm{mmol} \mathrm{dm}^{-3} ; \mathrm{H}+\mathrm{Al}$ $24 \mathrm{mmol} \mathrm{dm}^{-3}$; SB $51 \mathrm{mmol} \mathrm{dm}^{-3} ; 68 \% \mathrm{~V}$; Organic matter $25 \mathrm{~g}$ $\mathrm{dm}^{-3}$; B $0.67 \mathrm{mg} \mathrm{dm}^{-3}$; Cu $2.6 \mathrm{mg} \mathrm{dm}^{-3}$; Fe $93 \mathrm{mg} \mathrm{dm}^{-3}$; Mn 5. $\mathrm{mg} \mathrm{dm}{ }^{-3}$; Zn $5.4 \mathrm{mg} \mathrm{dm}^{-3}$.

\section{Substrate procedure}

Regarding to the substrates, five samples were set; each sample weighed $100 \mathrm{~g}$ and was previously dried at $105^{\circ} \mathrm{C}$ for 24 hours to determine the field capacity (FC). Afterwards, samples were saturated with water $(200 \mathrm{~mL})$, measuring the water volume (not percolated) after 24 hours. Then, the FC volume was adjusted to $100 \%$ for the substrate. Finally, the tests were conducted in $5-\mathrm{L}$ pots, containing five kilograms of substrate, which was a mixture of soil and compost in 3:1 ratio, respectively.

\section{Irrigation method and management}

Irrigation was controlled by gravimetric method, i.e. adding the volume of water until the mass in the pots reached the predetermined value, considering the soil and water mass. Experimental plots were daily monitored until irrigation was withheld to keep them from $100 \%$ FC. 
Plants were evaluated by the time they reached harvesting point, i.e. 58 days after seedlings were transplanted. Soon after irrigation was withheld at different levels, the substrates showed FC up to $100 \%, 86 \%, 72 \%, 57 \%$ and $42 \%$, in treatments $0,3,6,9$ and 12 days of NS, respectively.

\section{Phytotechnical traits analysis}

Pyrotechnical characteristics were evaluated, i.e. shoot fresh mass (SFM), shoot dry mass (SDM), root fresh mass (RFM), root dry mass (RDM), root volume (RV), essential oil content (CONTENT) and oil yield (YIELD). Shoot and root fresh mass were measured on a digital scale. To determine the dry mass, each structure was individually placed in paper bags and kept in forced-air oven at $45^{\circ} \mathrm{C}$ until constant mass was reached. Root volume was determined by displacing the water volume in a graduated beaker $(1000 \mathrm{~mL})$.

\section{Essential oil extraction and analysis}

Regarding to the extraction of plants essential oil, it was selected the shoots of dried plants $(50 \mathrm{~g})$, which was chopped and submitted to hydrodistillation method by using Clevenger extraction apparatus for 2 hours. The oil was separated from hidrolact and transferred into polyethylene bottles, using an analytical balance to obtain the extracted oil mass. Based on mass, the content of essential oil was determined by the following equation: [C\% = oil mass (g) / $50 \mathrm{~g}$ (aerial part of dried plant for extraction) $\times 100]$; and oil yield per plant $\left[Y\left(\mathrm{mg} .50 \mathrm{~g}\right.\right.$ of plant $\left.^{-1}\right)=$ content of essential oil $x$ shoot biomass/100].

Regarding to the chemical composition of essential oils, it was performed a junction of two repetitions to minimize the number of experimental units, which reduced from forty to twenty. Quantitative analysis was performed by flame ionization detector for gas chromatography (GC-FID, Shimadzu GC-2010 / AOC-20i), provided with Fused-silica capillary column DB-5 (30 m x $0.25 \mathrm{~mm} \times 0.25 \mu \mathrm{m})$, helium as carrier gas, flow rate of $1.0 \mathrm{~mL} \mathrm{~min}^{-1}$, injector at $240^{\circ} \mathrm{C}$, detector at $230^{\circ} \mathrm{C}$, split $1 / 20$ and the following temperature

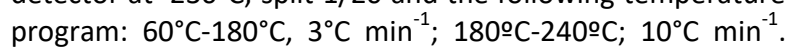
The qualitative analysis of chemical composition of essential oils has been conducted in a gas chromatography-mass spectrometer (GC-MS, Shimadzu QP-5000) operating at 70 eV, equipped with a Fused-silica capillary column OV-5 (30 m

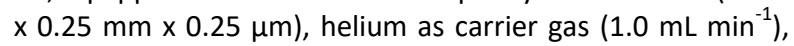
injection volume: $1 \mu \mathrm{L}$ of solution (i.e. $1 \mathrm{mg}$ of essential oil/ 1 $\mathrm{mL}$ of ethyl acetate), split: $1 / 20$, injector at $240^{\circ} \mathrm{C}$, detector at $230^{\circ} \mathrm{C}$ and the following temperature program: $60^{\circ} \mathrm{C}-$ $240^{\circ} \mathrm{C}, 3^{\circ} \mathrm{C} \mathrm{min}^{-1}$ (Van den Dool and Kratz, 1963).

The chemical components identification was performed by comparative analysis of mass spectrum of substances with the database GC-MS system (Nist62.lib), literature and substances retention. Retention rates were determined by injecting a homologous series of $n$-alkanes in the same programmed written temperature for GC-MS by applying the equation of Van den Dool and Kratz; (Adams, 2007).

\section{Statistical analysis}

Evaluated traits data was submitted to analysis of variance by means of $F$ test $(p<0.05)$. In Minitab 17 statistical software, a linear regression model was applied whether there was significant variation between evaluation of means.

\section{Conclusion}

Shoot dry mass, content and yield were not affected by withholding irrigation; reducing agriculture water use.

The major component found in the essential oil was piperitenone oxide. However, this component does not change due water stress. Water stress altered the following components concentrations: 3-octanol; limonene; linalool; 3-octanol, acetate; $\mathrm{p}$-Cymen-8-ol and cis-Piperitone epoxide.

\section{References}

Abbaszadeh B, Farahani HA, Morteza E (2009) Effects of irrigation levels on essential oil of balm (Melissa officinalis L.). Am Eursian J Sustain Agric. 3(3): 53-56.

Adams RP (2007) Identification of essential oil components by gas chromatography/mass spectrometry. 4 ed. Allured Publishing Corporation, Illinois, USA. 804 p.

Agência Nacional de Águas (2016) Conjuntura dos recursos hídricos no Brasil. ANA, Brasília, Brasil. 95 p.

Andrade FMC, Casali VWD (1999) Plantas medicinais e aromáticas: relação com o ambiente, colheita e metabolismo secundário. UFV, Viçosa, Brasil. 139 p.

Delfine S, Loreto F, Pinelli P, Tognetti R, Alvino A. (2005) Isoprenoids content and photosynthetic limitations in rosemary and spearmint plants under water stress. Agric Ecosyst Environ. 106(2-3): 243-252.

Farahani HA, Valadabadi SA, Daneshian J, Khalvat MA (2009) Evaluation changing of essential oil of balm (Melissa officinalis L.) under water deficit stress conditions. J. Med Plant Res. 3(5): 329-333.

Harborne JB (1997) Biochemical plant ecology. In: Dey PM, Harborne, JB (Eds) Plant Biochemistry. Academic Press, London, UK. 554 p.

Marcum DB, Hanson BR (2006) Effect of irrigation and harvest timing on peppermint oil yield in California. Agr Water Manage. 82(1-2): 118-128.

Matos FJA, Machado MIL, Craveiro AA, Alencar JW, Barbosa JM, Cunha, EVL, Hiruma CA. (1999). Essential Oil of Mentha $x$ villosa Huds. from Northeastern Brazil. J Essent Oil Res. 11(1): 41-44.

Meira MR, Melo MTP, Martins ER, Pinto MJS, Santana CS (2013) Crescimento vegetativo, produção de fitomassa e de óleo essencial de Melissa officinalis L. sob diferentes lâminas de irrigação. Cienc Rural. 43(5): 779785.

Paulus D, Medeiros SLP, Santos OS, Riffel C, Fabbrin EG, Paulus E (2005) Substratos na produção hidropônica de mudas de hortelã. Hortic Bras. 23(1): 48-50.

Pereira LS, Cordery I, lacovides I (2009) Coping with water scarcity: Addressing the challenges. Springer, Dordrecht, Netherlands. $382 \mathrm{p}$.

Pravuschi PR, Marques PAA, Rigolin BH, Santos ACP (2010) Efeito de diferentes lâminas de irrigação na produção de óleo essencial do manjericão (Ocimum basilicum L.). Acta Sci-Agron. 32(4): 687-693. 
Shabih Fatima AH, Abad F, Srikant S (2002) Physiological and metabolic responses of different genotypes of Cymbopogon martinii and C. winterianus to water stress. Plant Growth Regul. 37(2): 143-149.

Taiz L, Zeiger E (2013) Fisiologia vegetal. Zeiger, E, Oliveira PL (eds). 5 ed . Artmed, Porto Alegre, Brasil. $719 \mathrm{p}$.
Van den Dool H, Kratz DJ (1963) A generalization of the retention index system including linear temperature programmed gas-liquid partition chromatography. J Chromatogr. 11:463-467.

Wildung MR, Croteau, RB (2005). Genetic engineering of peppermint for improved essential oil composition and yield. Transgenic Res. 14(4): 365-372. 